\title{
Death Relationship
}

National Cancer Institute

\section{Source}

National Cancer Institute. Death Relationship. NCI Thesaurus. Code C82563.

An indication or description of a correlation between death and another event. 